\title{
Sense of coherence among patients with rheumatoid arthritis
}

Poczucie koherencji u pacjentów z reumatoidalnym zapaleniem stawów

Mariola Ejdys, Olga Bielan

Katedra Pielęgniarstwa, Wydział Nauk Medycznych, Uniwersytet Warmińsko-Mazurski w Olsztynie

CORRESPONDING AUTHOR/AUTOR DO KORESPONDENCJ:

Mariola Ejdys

Katedra Pielęgniarstwa, Wydział Nauk Medycznych, Uniwersytet Warmińsko-Mazurski w Olsztynie

ul. Żołnierska 14 c, 10-229 Olsztyn e-mail: mariola.ejdys@uwm.edu.pl

\section{STRESZCZENIE}

Słowa kluczowe:

\section{ABSTRACT}

Key words:

\section{POCZUCIE KOHERENCJ U PACJENTÓW Z REUMATOIDALNYM ZAPALENIEM STAWÓW}

Wprowadzenie. Poczucie koherencji (SOC-29) wyjaśnia związek ze zdrowiem. Wysokie SOC u pacjentów z reumatoidalnym zapaleniem stawów daje wiarę w sens życia. Sprawia, że chce się być zdrowym i sprawnie funkcjonować.

Cel pracy. Celem pracy była ocena poczucia koherencji u pacjentów z reumatoidalnym zapaleniem stawów.

Materiał i metody. Badania zostały przeprowadzone w 2014 r., wśród 120 pacjentów z klinicznie rozpoznanym reumatoidalnym zapaleniem stawów (r.z.s), którzy byli objęci stacjonarną opieką w oddziale Reumatologii, w jednym z olsztyńskich szpitali. Ankietowani świadomie wyrazili zgodę na udział w badaniu. W trakcie badania posłużono się, kwestionariuszem Orientacji Życiowej (SOC- 29). Narzędzie zawierało 29 pytań odnoszących się do różnych aspektów życia.

Wyniki. Średnia wartość wskaźnika koherencji w badanej grupie wyniosła 137 pkt. Spośród składowych komponentów poczucia koherencji, najwięcej punktów uzyskali pacjenci z poczuciem zaradności 48, 97 pkt, następnie z poczuciem zrozumiałości 45,73 pkt. Jednocześnie najmniej punktów uzyskali pacjenci z poczuciem sensowności 42,3 pkt.

Wnioski. Ogólny wskaźnik poczucia koherencji w badanej grupie pacjentów z r.z.s. ukształtował się na poziomie 137 pkt. i mieści się w zakresie średnich wartości normatywnych uzyskiwanych przez Antonovsky'ego. Najwyższym wskaźnikiem poczucia koherencji cechowali się pacjenci poniżej 30. r.ż., jednocześnie posiadali najwyższe poczucie zaradności i sensowności. Natomiast wyższy poziom poczucia zrozumiałości charakteryzował pacjentów pomiędzy 31. a 40. rokiem życia.

poczucie koherencjil, reumatoidalne zapalenie stawów

\section{SENSE OF COHERENCE AMONG PATENIS WITH RHEUMATOID ARTHRITIS}

Introduction. Sense of coherence (SOC-29) clarifies the relationship with health. High SOC in patients with rheumatoid arthritis puts faith in the meaning of life. Makes you want to be healthy and be able to function.

Aim. Aim of this study was to evaluate the sense of coherence in patients with rheumatoid arthritis.

Material and methods. The study was conducted in 2014, consisting of 120 patients with clinically diagnosed RA, who were covered by a stationary health care in a rheumatology department in one of hospitals in 0lsztyn. Respondents knowingly gave oral consent to participate in the study. During the study, were used a questionnaire (SOC-29). The tool contains 29 questions relating to various aspects of life.

Results. The mean of coherence in the study group was 137 points. Among the constituent components of $\mathrm{SOC}$, patients received the highest score in the category of a sense of manageability, 48.97 points, followed by a sense of rationality 45.73 points, and a sense of meaningfulness of 42.3 points.

Conclusions. The overall rate of $\mathrm{SOC}$ in the group of patients with rheumatoid arthritis reached the level of 137 points and is located in the middle of normative earned by Antonovsky. The highest rate of $\mathrm{SOC}$ patients were characterized by an under 30 years of age, also had the highest sense of manageability and reasonableness. However, a higher level of sense of rationality characterized patients between 31 and 40 years.

sense of coherence (SOC), rheumatoid arthritis 


\section{INTRODUCTION}

Rheumatoid arthritis (RA) is a chronic systemic connective tissue disease, immune mediated. It is characterized by nonspecific, symmetrical inflammation of the joints, extra-articular changes and organ damage complications [1]. It is a progressive inflammatory process starting in the synovial membrane of joints, leading to destruction of joint tissues, distortion and impaired joint function [2]. In spite of the treatment, most patients have a chronic, relapsing disease, that leads to joint destruction, deformity, disability and premature death [3]. The disease occurs in people of all ages, with the predominant people from 30 to 60 years old. The incidence of R.A., depending on the population, ranges from 0.5 to $2 \%$, of which women suffer three times more often than men. The incidence is about 50 cases per 160 thousand residents. In Poland, it is estimated that at R.A. suffers approx. $1 \%$ of the population, which means that the disease is the cause of disability and invalidity of about 400,000 people [2].

The disease process once started, does not expire and slowly progress [3]. However, it allows patients to function as normally as possible, both - in the family and in the society, but causing certain restrictions. Immunology resources that are owned by every human and environment, contribute to a certain type of life experience, shaping the sense of coherence [4].

Aaron Antonovsky proposed and developed the concepts of salutogenesis, in which a key element of the assessment is the sense of coherence. According to Antonvsky's sense of coherence is the belief that events and processes experienced by the human, will proceed with its own expectations, and the world is orderly and predictable. In addition, a strong sense of coherence makes a person organize adequate resources for a given situation and put them to take full advantage. According to Aaron Antonovsky, sense of coherence consists of three elements [4]:

- sense of comprehensibility - allows to see the world as a more orderly and predictable,

- sense of manageability - allowing to cope with difficult situations,

- sense of meaningfulness - expressing the will to live and the belief that it is worth to get involved and create our own lives.

An important element of this concept is that high sense of coherence, prevents the transformation of emotional disorders, especially anxiety and depressive disorders in a state of stress and alleviates the detrimental effects of emotional stress [4]. In the opinion of specialists, people with a high sense of coherence are predisposed to react in stressful situations with emotions that are consciously experienced, form the basis of a predisposition to action and trigger more coping mechanisms. In contrast, patients with a weak sense of coherence react to the disease and its consequences emotional with disorders, particularly with depression and anxiety.
Given the above and the fact that the disease affects many areas of functioning of patient, it seems important to draw attention to the influence of sense of coherence on the life of the patient, the manner of perceiving and understanding the world. For a contemporary model of medical care it is important to the subjective dimension of the disease and the active participation of the patient in therapy for the preservation of quality of life.

\section{AIM}

Aim of this study was to evaluate the sense of coherence in patients with rheumatoid arthritis.

\section{MATERIALS AND METHODS}

The study was conducted in 2014, among the 120 patients with clinically diagnosed rheumatoid arthritis (RA), who were covered by stationary health care in rheumatology department in one of hospitals in Olsztyn.

All the respondents knowingly gave verbal consent to participate in the study. The study used a method of diagnostic survey and research technique was a form. As a research tool, during the test, Life Orientation Questionnaire (SOC-29) was used. The tool consisted of 29 questions, relating to various aspects of life.

Sense of coherence is described by three components - comprehensibility, manageability and reasonableness. It is considered a relatively permanent feature, which shapes from childhood to the age of early maturity, when the person reaches his characteristic sense of coherence levels. The questionnaire consists of 29 questions relating to various aspects of life. The questions are divided into three sub-scales corresponding each component of sense of coherence: the sense of comprehensibility (SC), manageability (SMA) and meaningfulness (SME). Rating of Polish version of SOC-29 showed high reliability of tool (Cronbach's alpha index $=0.78$ ). In addition, shortened version of questionnaire "Perceptions of disease B-IPQ” in Polish translation of Katarzyna Nowicka-Sauer, was used. The questionnaire includes questions relating to the socio-demographic characteristics and 8 statements that describe the consequences of ill health among other things, restrictions, a sense of dependence on other and self lower-esteem.

\section{RESULTS}

The study group consisted of patients with clinically diagnosed rheumatoid arthritis, who were covered by stationary health care in rheumatology ward in one of the hospitals in Olsztyn. This group consisted of 120 patients, aged from 20 to 73 , of which 92 were women $(76.67 \%)$ and 28 were men $(23.33 \%)$. Of the respondents, largest percentage of patients were with vocational education (36.66\%), while the third largest group, were those with higher education (23.33\%). The respondents with secondary education accounted for $(26.66 \%)$ and primary education for $(13.34 \%)$. 
Mariola Ejdys, Olga Bielan

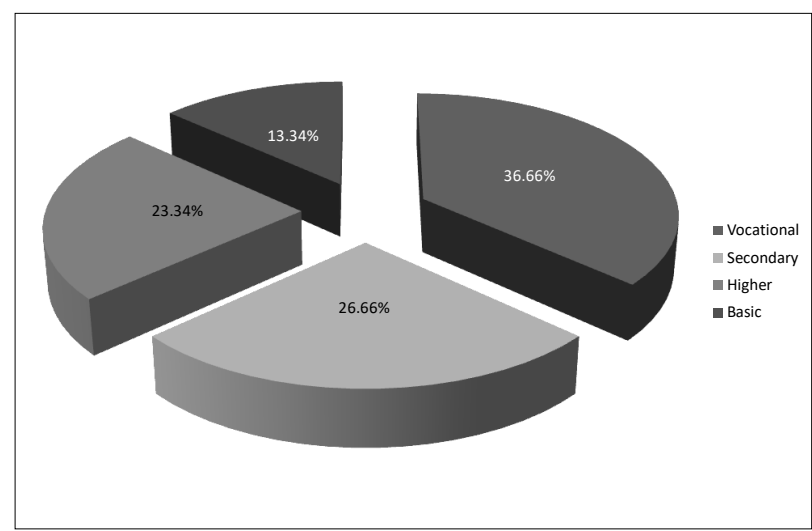

Fig 1. Structure of education

Employment in the group stated 36 (30\%) of respondents, on a disability pension, there were $56(46.67 \%)$ of respondents, while retired $24(20 \%)$. Currently, disciples were 4 , ie. $(3.33 \%)$ patients.

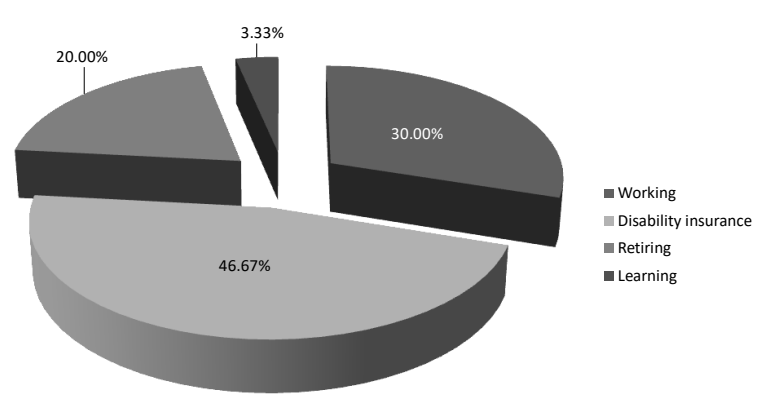

Fig 2. Structure of profession.

The total rate of feeling the coherence in the examined group of patients amounted on level of 137 points. Moreover, achieved results show that feeling the resourcefulness is an important component of feeling the coherence - $48.97 \mathrm{pt}$, next feeling the intelligibility - 45.73 the pt, and feeling of the sense 42.3 pt. It is also important to add that above ingredients remain with themselves in determined connections. It is assumed that feeling the resourcefulness has a significant influence on the height or a fall in remaining ingredients. When feeling the resourcefulness is strong, remaining elements are also having a tendency to grow. However, when feeling the resourcefulness is weak, then remaining elements have a downward trend. Taking into consideration both theoretical premises and current examinations it is possible to think that thanks to feeling the resourcefulness patients with rheumatoid arthritis are able to advise oneself with problems of the everyday life. It is also possible that shown sense is supporting the greater readiness for taking new motor activities.

Which can protect before evoking negative emotions such as: sadness, fear and anger. This belief is gaining the special significance in the face of the destruction and the deformation of ponds, disability and the untimely death.

Therefore the faith associated with high feeling the coherence in the meaning of the life is giving the base to so that the man can like longest efficiently to function in surrounding world.
Tab. 1. Sense of coherence and its components in the studied group of patients with RA.

\begin{tabular}{|l|c|c|c|c|c|}
\hline \multicolumn{1}{|c|}{$\begin{array}{c}\text { Sense of } \\
\text { coherence }\end{array}$} & $\begin{array}{c}\text { Size of } \\
\text { sample }\end{array}$ & $\begin{array}{c}\text { Minimal } \\
\text { value }\end{array}$ & $\begin{array}{c}\text { Maximal } \\
\text { value }\end{array}$ & $\begin{array}{c}\text { Arithmetic } \\
\text { average }\end{array}$ & $\begin{array}{c}\text { Standard } \\
\text { deviation }\end{array}$ \\
\hline Overall rate & 120 & 99 & 186 & 137 & 20.82 \\
\hline $\begin{array}{l}\text { Sense of } \\
\text { comprehensibility }\end{array}$ & 120 & 25 & 71 & 45.73 & 9.94 \\
\hline $\begin{array}{l}\text { Sense of } \\
\text { manageability }\end{array}$ & 120 & 32 & 65 & 48.97 & 9.12 \\
\hline $\begin{array}{l}\text { Sense of } \\
\text { meaningfulness }\end{array}$ & 120 & 24 & 56 & 42.3 & 8.83 \\
\hline
\end{tabular}

The highest overall rate of SOC received the patients younger than 30 years old - 152 points, between the ages of 31 to 40 years old, they gained 146.4 points. In contrast, patients in the age group of 41 to 50 , gained 141.56 points. Respondents between the ages of 51 to 60 gained 131.51 points. The lowest rate of SOC received patients older than 60 years old - 130.64 pts.

Tab. 2. The overall rate of SOC in patients with RA in different age groups.

\begin{tabular}{|l|c|c|c|c|c|}
\hline \multirow{2}{*}{$\begin{array}{c}\text { Age } \\
\text { group }\end{array}$} & \multicolumn{5}{|c|}{ Sense of coherence } \\
\cline { 2 - 6 } & $\begin{array}{c}\text { Size of } \\
\text { sample }\end{array}$ & $\begin{array}{c}\text { Minimal } \\
\text { value }\end{array}$ & $\begin{array}{c}\text { Maximal } \\
\text { value }\end{array}$ & $\begin{array}{c}\text { Arithmetic } \\
\text { average }\end{array}$ & $\begin{array}{c}\text { Standard } \\
\text { deviation }\end{array}$ \\
\hline$<30$ & 8 & 128 & 164 & 152 & 16.27 \\
\hline $31 \div 40$ & 10 & 131 & 183 & 146.4 & 21.88 \\
\hline $41 \div 50$ & 36 & 101 & 186 & 141.56 & 22.22 \\
\hline $51 \div 60$ & 44 & 99 & 182 & 131.51 & 19.72 \\
\hline$>60$ & 22 & 107 & 161 & 130.64 & 18.72 \\
\hline
\end{tabular}

The average rate of sense of comprehensibility was highest in the group between 31 and 40 years old - 49.8 points. In contrast, patients between 41 and 50 years old obtained 46.78 points. Respondents under 30 years old gained 46.75 points and the subjects between 51 and 60 years old obtained 44.82 points. In contrast, the group of respondents over 60 years old gained 43.64 points.

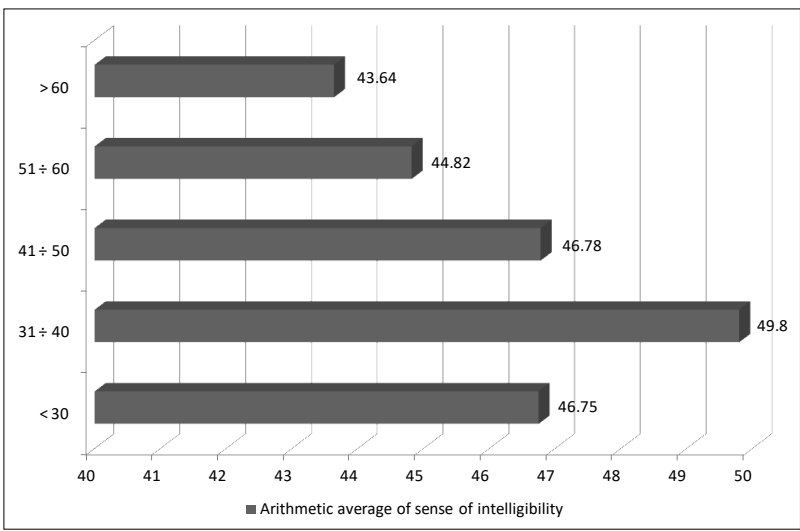

Fig 3. Index of the sense of comprehensibility in different age groups in the investigated group of patients with RA.

The average rate sense of manageability was highest in the group of patients between 41 and 50 years old and amounted 50.78 points. Respondents between 31 and 40 years old reached 50.6 points. Indicator of patients, between 51 and 60 years old, reached 46.09 points, and respondents over 60 years old averaged 49 points. 


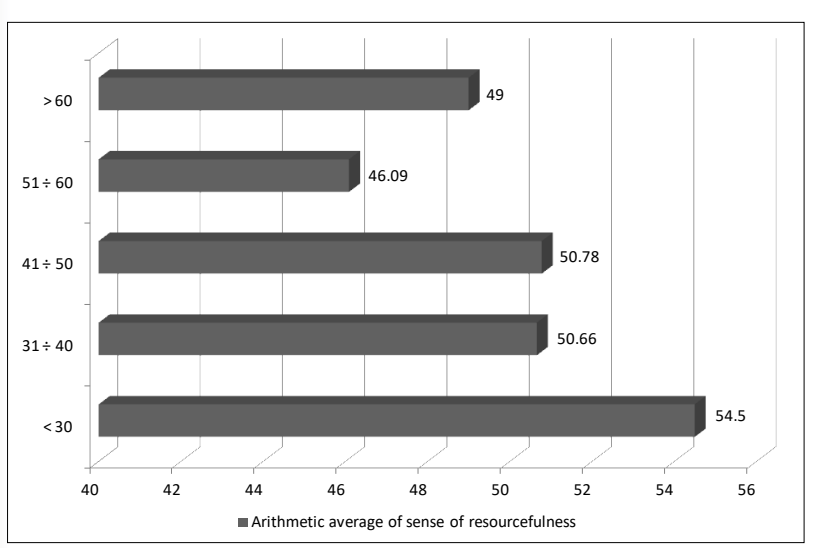

- Fig 4. Index of the sense of meaningfulness in different age groups in the investigated group of patients with RA.

The average rate of sense of meaningfulness was highest among the patients below 30 years old and amounted 50.75 points. Respondents between 41 and 50 years old reached 44 points. Patients in the age group between 51 and 60 years old achieved 40.68 points. The lowest score of 38 points, averaged respondents above 60 years old.

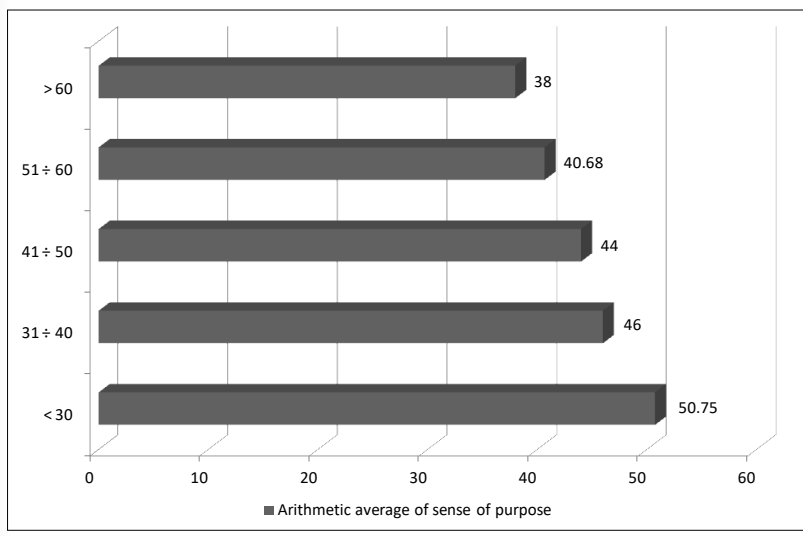

Fig 5. Index of the sense of manageability in different age groups in the investigated group of patients with RA.

\section{DISCUSSION}

In the opinion of the three components of sense of coherence (comprehensibility, manageability and meaningfulness) patients with rheumatoid arthritis, highest number of points obtained in the field of component of sense of manageability 48.97 points. In contrast, the component of comprehensibility score stood at 45.73 points. At the same time in terms of the component sense of meaningfulness, patients received 42.3 points.

The highest overall rate of sense of coherence, received patients younger than 30 years old - 152 points. Patients aged between 31 and 40 years old received 146.4 points. In contrast, patients in the age group between 41 and 50 years old gained 141.56 points. Furthermore, patients aged between 51 and 60 years old gained 131.51 points. While the lowest rate of SOC - 130.64 points, received patients over 60 years old.

Average SOC level was within an ordinary range values obtained by Antonovsky. Considering the sense of meaningfulness within respondents, the average was 42.3 points. The maximum score was 53 points, while the minimum was 24 points. According to Antonovsky level of meaningfulness, plays the most important role, justified by the fact, that a man with a high sense of comprehensibility and high sense of manageability, acquainted with the functioning of their disease which is rheumatoid arthritis, quickly cease to understand what was happening around him and quickly loses control over resources if you will not have the motivation (sense of meaningfulness) [5]. Lowest sense of meaningfulness showed patients over 60 years of age 38 pts., While the highest sense of meaningfulness received patients under 30 years of age, ie. 50.75 points.

Led by Wlazło and her team, study of SOC confirmed these results, probably due to the fact that RA is a chronic disease, the patients began to adapt to the changes that have occurred in their lives, and regained the ability to make events predictable, and also found in themselves new resources, allowing them to actively influence the situation [6].

Patients with high sense of coherence rarely recognize the stimuli received as stressors and thus less likely to be for them to assert to the emergence of anxiety and depressive disorders. [5]. These people choose their way of dealing with stress appropriate to the situation [4]. In his research Pasikowski showed, that the ability to use resources most correlates the sense of meaningfulness, as confirmed by the above study of authors. In addition, also he showed that the higher sense of coherence, the greater the likelihood that stress stimuli will be perceived as a challenge than as a threat or any loss. Wrześniewski and his team showed in their study that the stronger sense of comprehensibility, manageability and meaningfulness, the lower the tendency to experience negative emotions [7]. Has also been proven that the mere recognition of the ability to control stressors that declare a person with a high sense of coherence correlates negatively with negative changes in the level of physiological response $[8,9]$. Diagnosis of chronic disease brings a lot of changes in the lives of the sick, disorganizing his family life, forcing modifications of existing relationships. The emergence of the disease in the family causes emotional and material costs. The disease can be an obstacle in getting a profession, continuing education or previous work. Professional work is a motivating factor to maintain the efficiency and regular treatment.

\section{CONCLUSIONS}

1. The level of sense of coherence in the group of patients with rheumatoid arthritis stood at 137 points and was in the range of ordinary values obtained by Antonovsky.

2. The highest indicator of sense of coherence were characterized by patients under 30 years of age, at the same time they had the highest sense of manageability and meaningfulness. In contrast, a higher level of sense of comprehensibility characterized patients between 31 and 40 years of age.

3. The lowest index of sense of coherence was gained by patients over 60 years of age, they averaged 130.64 points. 


\section{Poczucie koherencji u pacjentów z reumatoidalnym zapaleniem stawów}

\section{WPROWADZENIE}

Reumatoidalne zapalenie stawów (r.z.s.) jest przewlekłą układową choroba tkanki łącznej, o podłożu immunologicznym. Charakteryzuje się nieswoistym zapaleniem symetrycznym stawów, zmianami zastawowymi oraz powikłaniami narządowymi [1]. Jest postępującym procesem zapalnym rozpoczynającym się w błonie maziowej stawów, prowadzący do niszczenia tkanek stawowych, zniekształceń i upośledzenia czynności stawów [2]. Mimo stosowanej terapii, przebieg choroby u większości chorych ma charakter przewlekły $z$ nawrotami, prowadzący do destrukcji stawów, deformacji, niepełnosprawności i przedwczesnej śmierci. Choroba występuje u osób w różnym wieku. Wśród chorych przeważają ludzie w wieku od 30 do 60 lat, kobiety chorują trzy razy częściej niż mężczyźni. Proces chorobowy raz rozpoczęty nie wygasa i powoli postępuje. Częstość występowania r. z. s. w zależności od populacji waha się od 0,5 do $2 \%$. Zachorowalność wynosi około 50 przypadków na 160 tyś. mieszkańców. W Polsce szacuje się, że na r. z. s. choruje ok. 1\% populacji, co oznacza, że choroba jest przyczyną niepełnosprawności i inwalidztwa około 400 tysięcy osób [3].

Powolny proces chorobowy pozwala pacjentom $\mathrm{w}$ miarę normalnie funkcjonować w rodzinie i społeczeństwie, powoduje określone ograniczenia. Zasoby odpornościowe, które są własnością każdego człowieka i środowiska, przyczyniają się do występowania pewnego typu doświadczeń życiowych, kształtujących poczucie koherencji [4].

Aron Antonovsky zaproponował i rozwinął koncepcje salutogenezy, w której kluczowym elementem oceny jest poczucie koherencji. Zdaniem Antonvsky'ego poczucie koherencji jest przekonaniem, że zdarzenia i procesy doświadczane przez człowieka będą przebiegały z jego własnymi oczekiwaniami, a świat ma charakter uporządkowany i przewidywalny. Ponadto silne poczucie koherencji sprawia, że człowiek organizuje adekwatne dla danej sytuacji zasoby i umie je w pełni wykorzystać. Według w/w autora, poczucie koherencji składa się z trzech elementów [4]:

- poczucia zrozumiałości - pozwalającego widzieć świat jako bardziej uporządkowany i przewidywalny,

- poczucia zaradności - umożliwiającego radzenie sobie w sytuacjach trudnych,

- poczucia sensowności - wyrażającego wolę życia i przekonania, że warto się angażować i kreować własne życie.

Ważnym elementem powyższej koncepcji jest to, że wysoki wskaźnik poczucia koherencji, zapobiega przekształcaniu się zaburzeniom emocjonalnym, a szczególnie lęku i zaburzeniom depresyjnym w stan stresu oraz łagodzi szkodliwe skutki napięć emocjonalnych [4]. W opinii specjalistów osoby z wysokim poczuciem koherencji są predysponowane do reagowania w sytuacjach stresowych emocjami, które są świadomie przeżywane, stanowią bazę predyspozycji do działania i w większym stopniu wyzwalają mechanizmy radzenia sobie. Natomiast pacjenci ze słabym poczuciem koherencji reagują na chorobę oraz jej konsekwencje zaburzeniami emocjonalnymi w szczególności depresją i lękiem.

Biorąc pod uwagę powyższe oraz to, że choroba dotyka wielu sfer funkcjonowania pacjenta, istotne wydaje się zwrócenie uwagi na wpływ poczucia koherencji na życie chorego, na sposób spostrzegania i rozumienia świata. Albowiem we współczesnym modelu opieki medycznej ważny jest subiektywny wymiar choroby oraz aktywny udział pacjenta w terapii na rzecz zachowania jakości życia.

\section{CEL PRACY}

Celem pracy była ocena poczucia koherencji u pacjentów chorych na reumatoidalne zapalenie stawów.

\section{MATERIAL, METODY I WYNIKI BADAŃ}

Badania zostały przeprowadzone w 2014 r., wśród 120 pacjentów $z$ klinicznie rozpoznanym reumatoidalnym zapaleniem stawów (r.z.s), którzy byli objęci stacjonarną opieką w oddziale reumatologii, w jednym z olsztyńskich szpitali.

Wszyscy ankietowani świadomie wyrazili ustną zgodę na udział w badaniu. W badaniu zastosowano metodę sondażu diagnostycznego, a techniką badawczą była ankieta. Jako narzędzie badawcze wykorzystano kwestionariusz ankiety. W trakcie badania posłużono się, kwestionariuszem Orientacji Życiowej (SOC- 29). Narzędzie zawierało 29 pytań odnoszących się do różnych aspektów życia.

Poczucie koherencji opisane jest przez trzy wymiary zrozumiałość, zaradność i sensowność. Jest ono uważane za cechę względnie trwałą, która kształtuje się od okresu dzieciństwa do wieku wczesnej dojrzałości, kiedy to osoba osiąga charakterystyczny dla siebie poziom poczucia koherencji. W skład kwestionariusza wchodzi 29 pytań odnoszących się do różnych aspektów życia, są podzielone na trzy podskale odpowiadające składowym poczucia koherencji: poczucie zrozumiałości (PZR), zaradności (PZ) i sensowności (PS). Ocena polskiej wersji SOC-29 wykazała wysoką rzetelność narzędzia (wskaźnik alfa Cronbacha $=0,78$ ). Dodatkowo wykorzystano skrócony kwestionariusz Percepcji choroby B-IPQ w polskim tłumaczeniu Katarzyny Nowickiej - Sauer. W skład kwestionariusza wchodzą pytania odnoszące się do cech demograficzno-społecznych oraz 8 stwierdzeń opisujących konsekwencje złego stanu zdrowia między innymi ograniczenia, poczucie zależności od innych, obniżenie własnej wartości. 
Badaną grupę stanowili pacjenci z klinicznie rozpoznanym reumatoidalnym zapaleniem stawów, którzy byli objęci stacjonarną opieką oddziału reumatologii w jednym z olsztyńskich szpitali. Powyższa grupa to 120 pacjentów w wieku od 20. do 73 roku życia, w tym 92 kobiet (76,67\%) oraz 28 mężczyzn (23,33\%). Spośród badanych największy odsetek stanowili pacjenci $\mathrm{z}$ wykształceniem zawodowym $(36,66 \%)$, natomiast $\mathrm{z}$ wykształceniem wyższym odsetek badanych stanowił (23,33\%). Ankietowani $\mathrm{z}$ wykształceniem średnim stanowili $(26,66 \%)$ oraz z wykształceniem podstawowym (13,34\%).

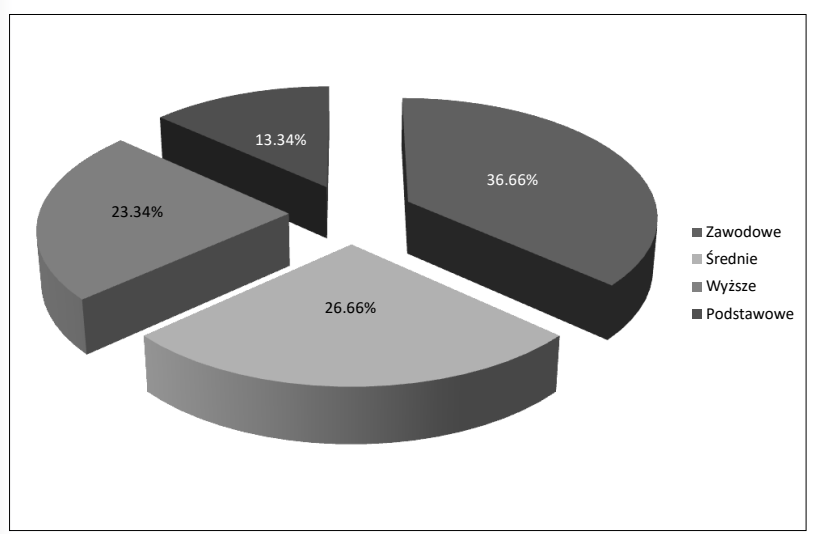

Ryc 1. Struktura wykształcenia.

Zatrudnienie w badanej grupie podawało 36 (30\%) ankietowanych, na rencie inwalidzkiej przebywało 56 $(46,67 \%)$ ankietowanych, natomiast na emeryturze 24 $(20 \%)$ respondentów oraz aktualnie uczniami było $4 \mathrm{tj}$. (3,33\%) pacjentów.

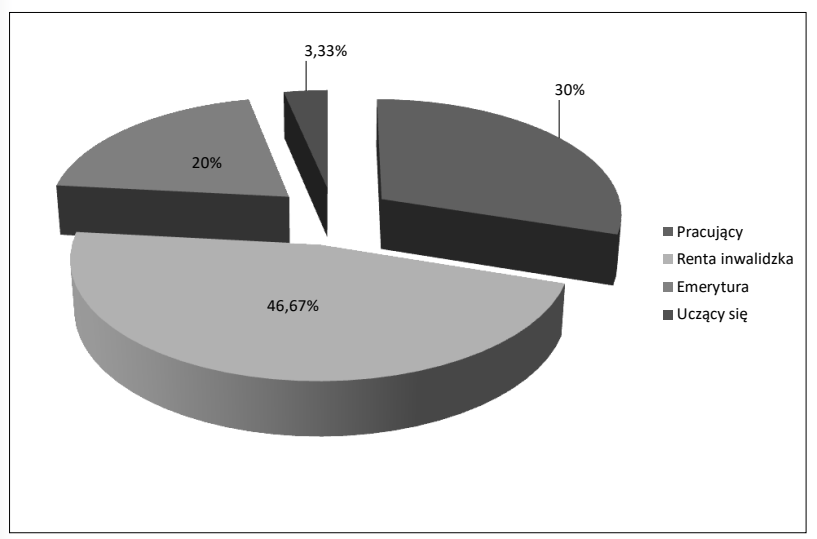

Ryc 2. Struktura zawodowa.

Ogólny wskaźnik poczucia koherencji w badanej grupie pacjentów ukształtował się na poziomie 137 pkt. Ponadto, uzyskane wyniki wskazują, że najważniejszym składnikiem poczucia koherencji jest poczucie zaradności - 48,97 pkt. następnie poczucie zrozumiałości - 45,73 pkt. i poczucie sensowności 42,3 pkt. Należy też dodać, że powyższe składniki pozostają ze sobą w określonych związkach. Zakłada się, że poczucie zaradności ma istotny wpływ na wzrost lub spadek pozostałych składników. Gdy poczucie zaradności jest silne, również pozostałe elementy mają tendencję do wzrostu. Natomiast, gdy poczucie zaradności jest słabe, wtedy pozostałe składniki mają tendencję spadkową. Biorąc pod uwagę zarówno prze- słanki teoretyczne jak i dotychczasowe badania można sądzić, że dzięki poczuciu zaradności pacjenci z r.z.s. są $\mathrm{w}$ stanie poradzić sobie z trudnościami życia codziennego. Możliwe też, że wskazane poczucie sprzyja większej gotowości do podejmowania nowych aktywności ruchowych. Co z kolei może zabezpieczać przed wywoływaniem negatywnych emocji takich jak: smutek strach i złość. To przekonanie nabiera szczególnego znaczenia w obliczu destrukcji i deformacji stawów, niepełnosprawności i przedwczesnej śmierci.

Tab. 1. Poczucie koherencji i jej składowe w badanej grupie chorych z r.z.s.

\begin{tabular}{|c|c|c|c|c|c|}
\hline $\begin{array}{c}\text { Poczucie } \\
\text { koherencji }\end{array}$ & 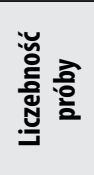 & 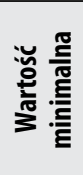 & 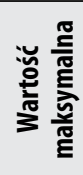 & 赵 & 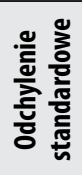 \\
\hline \begin{tabular}{|l|} 
Ogólny \\
wskaźnik
\end{tabular} & 120 & 99 & 186 & 137 & 20,82 \\
\hline $\begin{array}{l}\text { Poczucie } \\
\text { zrozumiałości }\end{array}$ & 120 & 25 & 71 & 45,73 & 9,94 \\
\hline \begin{tabular}{|l|} 
Poczucie \\
zaradności \\
\end{tabular} & 120 & 32 & 65 & 48,97 & 9,12 \\
\hline $\begin{array}{l}\text { Poczucie } \\
\text { sensowności }\end{array}$ & 120 & 24 & 56 & 42,3 & 8,83 \\
\hline
\end{tabular}

Najwyższy ogólny wskaźnik poczucia koherencji uzyskali pacjenci poniżej $30 \mathrm{r}$. ż. $152 \mathrm{pkt}$, w przedziale wiekowym od 31. do 40 r. ż. uzyskali 146,4 pkt. Natomiast pacjenci w grupie wiekowej od 41. do 50 lat uzyskali 141,56 pkt. Respondenci w przedziale wiekowym od 51. do 60 lat uzyskali 131,51 pkt. Natomiast najniższy wskaźnik poczucia koherencji uzyskali pacjenci powyżej $60 \mathrm{r}$. ż. 130,64 pkt.

Tab. 2. Ogólny wskaźnik poczucia koherencji w grupie chorych z r.z.S. w poszczególnych przedziałach wieku.

\begin{tabular}{|c|c|c|c|c|c|}
\hline $\begin{array}{c}\text { Poczucie } \\
\text { koherencji }\end{array}$ & 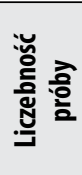 & 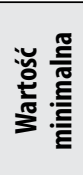 & 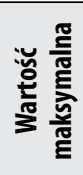 & 赵 & 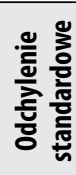 \\
\hline$<30$ & 8 & 128 & 164 & 152 & 16,27 \\
\hline $31 \div 40$ & 10 & 131 & 183 & 146,4 & 21,88 \\
\hline $41 \div 50$ & 36 & 101 & 186 & 141,56 & 22,22 \\
\hline $51 \div 60$ & 44 & 99 & 182 & 131,51 & 19,72 \\
\hline$>60$ & 22 & 107 & 161 & 130,64 & 18,72 \\
\hline
\end{tabular}

Średni wskaźnik poczucia zrozumiałości najwyższy był w grupie między 31 . a 40 r. ż. 49,8 pkt. Natomiast pacjenci między 41. a 50 r. ż. uzyskali 46,78 pkt. Respondenci poniżej 30 r. ż. uzyskali 46,75 pkt, a badani między 51. a $60 \mathrm{r}$. ż. uzyskali 44,82 pkt. Natomiast grupa respondentów powyżej 60 r. ż. uzyskała 43,64 pkt. 


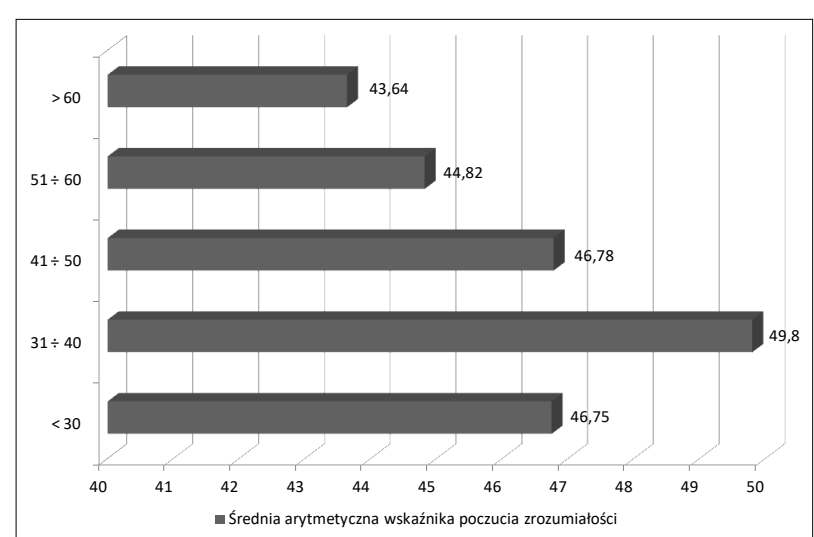

Ryc 3. Wskaźnik poczucia zrozumiałości w poszczególnych przedziałach wiekowych w badanej grupie chorych z r.z.s.

Średni wskaźnik poczucia zaradności najwyższy był w grupie badanych między 41. a 50 r. $\dot{z}$. i wynosił 50,78 pkt. Natomiast respondenci między 31. a 40 r. ż. osiągnęli 50,6 pkt. Pacjenci między 51. a 60 r. ż. osiągnęli wskaźnik rzędu 46,09 pkt., a respondenci powyżej 60 r. ż. 49 pkt.

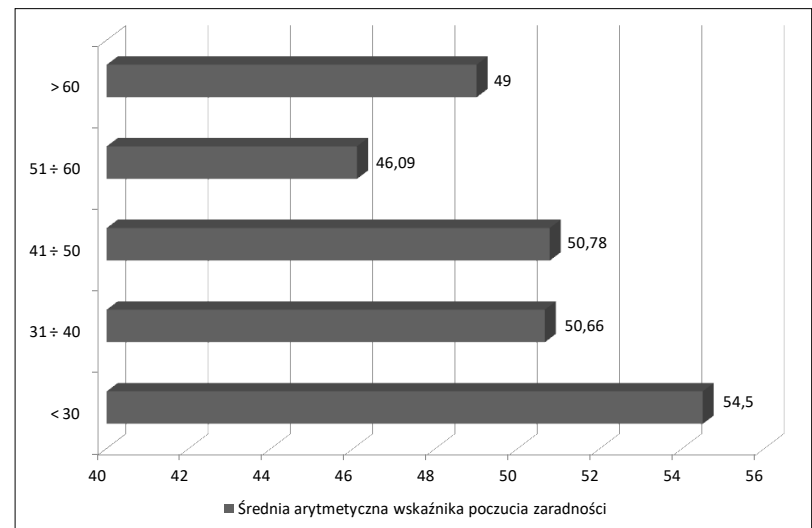

Ryc 4. Wskaźnik poczucia zaradności w poszczególnych przedziałach wiekowych w badanej grupie chorych z r.z.s.

Średni wskaźnik poczucia sensowności najwyższy był w grupie pacjentów poniżej 30 r. ż. i wyniósł 50,75 pkt. Natomiast respondenci między 41. a 50 r. ż. osiągnęli 44 pkt. Pacjenci w grupie wiekowej między 51. a 60 r. $\dot{z}$. osiągnęli 40,68 pkt, a najniższy wynik osiągnęli respondenci powyżej 60 r. ż. 38 pkt.

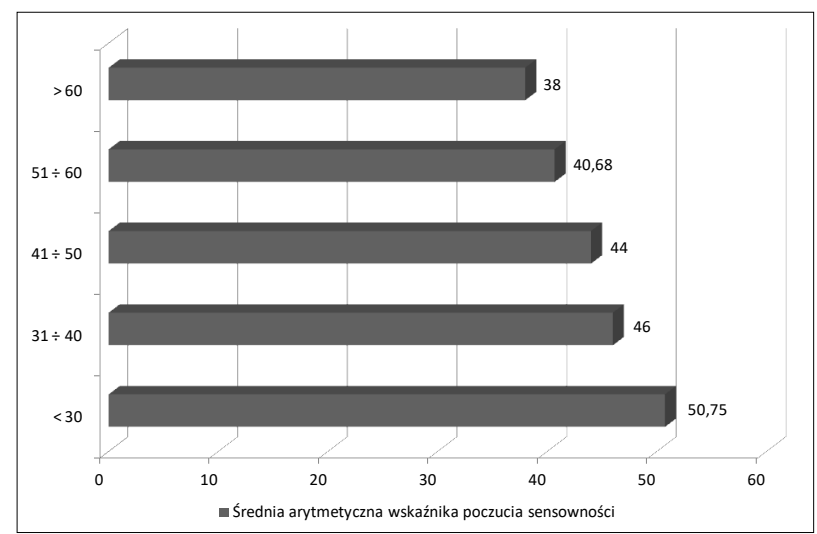

Ryc 5. Wskaźnik poczucia sensowności w poszczególnych przedziałach wiekowych badanej grupie chorych z r.z.s.

\section{DYSKUSJA}

W ocenie trzech komponentów poczucia koherencji (zrozumiałości, zaradności i sensowności) chorzy na reumatoidalne zapalenie stawów najwyższą ilość punktów uzyskali w zakresie komponentu poczucia zaradności 48,97 pkt. Natomiast w zakresie komponentu zrozumiałości wynik ukształtował się na poziomie 45,73 pkt. Jednocześnie w zakresie komponentu poczucia sensowności pacjenci uzyskali 42,3 pkt.

Najwyższy ogólny wskaźnik poczucia koherencji uzyskali pacjenci poniżej 30 roku życia tj.152 pkt. Pacjenci w przedziale wiekowym między 31. a 40 rokiem życia uzyskali $-146,4$ pkt. Natomiast pacjenci w przedziale wiekowym między 41. a 50 r. ż. życia uzyskali 141,56 pkt. Ponadto pacjenci w przedziale wiekowym między 51. a 60 rokiem życia uzyskali 131,51 pkt. Najniższy natomiast wskaźnik poczucia koherencji tj 130,64 pkt uzyskali pacjenci powyżej 60 roku życia.

Poziom średni SOC mieścił się w zakresie średnich wartości przeciętnych uzyskiwanych przez Antonovsky'ego. Rozpatrując poczucie sensowności respondentów, średnia wynosiła 42,3 pkt. Maksymalny wynik wynosił 53 pkt, natomiast minimalny to 24 pkt. Według Antonovsky’ego poziom sensowności odgrywa najważniejszą rolę, przemawia za tym fakt, że człowiek mający wysokie poczucie zrozumiałości i wysokie poczucie zaradności, znający zasady funkcjonowania w swojej chorobie jaką jest reumatoidalne zapalenie stawów, szybko przestanie rozumieć co się wokół niego dzieje i szybko traci kontrolę nad zasobami jeżeli nie będzie miał motywacji (poczucia sensowności) [5]. Najniższe poczucie sensowności wykazali pacjenci powyżej 60 roku życia 38 pkt., natomiast najwyższe poczucie sensowności uzyskali pacjenci poniżej 30 roku życia tj. 50,75 pkt.

Prowadzone przez Wlazło i wsp. badania poczucia koherencji potwierdzają powyższe wyniki, prawdopodobnie ze względu na to, iż r.z.s. jest chorobą przewlekłą, badani pacjenci zaczęli się przystosowywać do zmian, jakie zaszły w ich życiu, i odzyskali zdolność do porządkowania bodźców i czynienia zdarzeń przewidywalnymi, a także odnaleźli w sobie nowe zasoby pozwalające im aktywnie wpływać na sytuację.[6].

Pacjenci z wysokim poczuciem koherencji rzadziej uznają odbierane bodźce za stresor i tym samym rzadziej będzie u nich dochodzić do pojawienia się zaburzeń lękowych i depresyjnych [5]. Osoby te wybierają sobie sposób radzenia ze stresem adekwatny do sytuacji [4]. W swoich badaniach Pasikowski wykazał, że z umiejętnością korzystania z zasobów najsilniej koreluje poczucie sensowności, co potwierdziły powyższe badania autorki. Ponadto wykazał również, że im wyższe poczucie koherencji, tym większe prawdopodobieństwo, że bodźce stresowe będą postrzegane jako wyzwanie niż jako zagrożenie czy jakakolwiek strata. Wrześniewski i wsp. wykazali w swoich badaniach, że im silniejsze poczucie zrozumiałości, zaradności sensowności, tym mniejsza tendencja do przeżywania negatywnych emocji [7]. Udowodniono również, że już samo uznanie możliwości kontroli czynników stresujących, które deklarują osoby z wysokim poczuciem 
koherencji, koreluje ujemnie z negatywnymi zmianami na poziomie reakcji fizjologicznej $[8,9]$. Diagnoza choroby przewlekłej niesie ze sobą bardzo wiele zmian w życiu chorego, dezorganizując jego życie rodzinne, wymuszając modyfikacje dotychczasowych relacji. Pojawienie się $\mathrm{w}$ rodzinie choroby powoduje koszty emocjonalne oraz materialne. Choroba może być przeszkodą w zdobyciu zawodu, kontynuowaniu nauki lub dotychczasowej pracy. Praca zawodowa natomiast jest czynnikiem motywującym do aktywności, utrzymania sprawności oraz systematycznego leczenia.

\section{WNIOSKI}

1. Poziom poczucia koherencji w badanej grupie pacjentów z r.z.s. ukształtował się na poziomie 137 pkt. i mieścił się w zakresie średnich wartości przeciętnych uzyskiwanych przez Antonovsky'ego.

2. Najwyższym wskaźnikiem poczucia koherencji cechowali się pacjenci poniżej 30. r. ̇̇., jednocześnie posiadali najwyższe poczucie zaradności i sensowności. Natomiast wyższy poziom poczucia zrozumiałości charakteryzował pacjentów pomiędzy 31. a 40. rokiem życia.

3. Najniższy natomiast wskaźnik poczucia koherencji tj 130,64 pkt. uzyskali pacjenci powyżej 60 roku życia.

\section{PIŚMIENNICTWO/REFERENCES}

1. Głuszko P, Filipowicz-Sosnowska A, Tłustochowicz W. Reumatoidalne zapalenie stawów. Reumatologia. 2012; 50(2): 83-90.

2. Filipowicz-Sosnowska A, Stanisławska-Biernat B, Zubrzycka-Sienkiewicz A. Reumatoidalne zapalenie stawów. Reumatologia. 2004; 42 (1): 5-15.

3. Zimmermann-Górska I. Choroby reumatyczne. Warszawa: Wydawnictwo lekarskie PZWL; 2000, s. 54.

4. Antonovsky A. Rozwikłanie tajemnicy zdrowia. Warszawa: Instytut Psychiatrii i Neurologii. 2005, s. 34-35.

5. Wlazło A, Kleszczyński J, Dolińska-Żygmunt G, Leszek J. Wybrane zmienne psychologiczne u pacjentów z reumatoidalnym zapaleniem stawów i chorobą Gravesa-Basedowa. Neuropsychiatria i Neuropsychologia. 2008;3 (2): 71-79.

6. Gruszczyńska E, Worsztynowicz A. Koncepcja salutogenezy i poczucia koherencji A. Antonovsky'ego. Promocja zdrowia, Nauki Społeczne i Medycyna. 1999;17: 93-105.

7. Wrześniewski K, Łuszczyńska-Cieślak A, Włodarczyk D. Poczucie koherencji i zmiany emocjonalne u chorych poddanych rehabilitacji po zawale. Zdrowie-Stres-Zasoby. Poznań: Wydawnictwo Fundacji Humaniora; 2001, s.67-102.

8. Adams RJ, Daly A, Dal Grande E, Gill T. Psychological factorsand quality of life in arthritis: a population-based study. Clinical Rheumatology. 2007; 26 (5) 56-59.

9. Nowicka-Sauer K. Aspekty psychologiczne w Reumatologii. Psychologia w Medycynie - wybrane zagadnienia. Gdańsk: AMG; 2006; s.123-135.

Praca przyjęta do druku/Manuscript received: 07.03.2017

Praca zaakceptowana do druku/Manuscript accepted: 17.05.2017

Tłumaczenie/Translation: Natalia Zdanowska 